\title{
Glucosinolate Profile of Croatian Stenoendemic Plant Fibigia triquetra (DC.) Boiss. ex Prantl.
}

\author{
Ivica Blažević, ${ }^{1, *}$ Gina Rosalinda De Nicola, ${ }^{2}$ Sabine Montaut, ${ }^{3}$ Patrick Rollin, ${ }^{4}$ Mirko Ruščić ${ }^{5}$
}

\footnotetext{
1 University of Split, Faculty of Chemistry and Technology, Department of Organic Chemistry, Teslina 10/V, 21000 Split, Croatia

2 Consiglio per la ricerca in agricoltura e l'analisi dell'economia agraria - Centro di ricerca per le colture industriali (CREA-CIN), Via di Corticella 133, I-40128 Bologna, Italy

3 Department of Chemistry and Biochemistry, Biomolecular Sciences Programme, Laurentian University, 935 Ramsey Lake Road, Sudbury, ONP3E 2C6, Canada

${ }^{4}$ Université d'Orléans et CNRS, ICOA, UMR 7311, BP 6759, F-45067 Orléans, France

5 University of Split, Faculty of Sciences, Department of Biology, Teslina 12/V, 21000 Split, Croatia

* Corresponding author's e-mail address: blazevic@ktf-split.hr
}

RECEIVED: June 20, $2015 *$ REVISED: December 2, $2015 *$ ACCEPTED: December 9, 2015

Abstract: As part of our ongoing investigation of the stenoendemic plants belonging to the Brassicaceae family, we report on the chemistry of Fibigia triquetra (DC.) Boiss. ex Prantl for the first time. Different plant parts (flower, leaf, stem, and seed) of $F$. triquetra were characterized and quantified for glucosinolates (GLs) according to the ISO 9167-1 EU official method based on the HPLC analysis of desulfo-GLs. A taxonomic screening showed that F. triquetra contained relatively high levels of C-4 GLs, namely but-3-enyl GL (gluconapin, 1a), 4-methylsulfanylbutyl GL (glucoerucin, 3a), and 4-methylsulfinylbutyl GL (glucoraphanin, 5a). GC-MS analysis of the volatile fractions obtained after enzyme hydrolysis and/or HPLC-ESI-MS of intact GLs confirmed the GL profile. Four minor GLs, namely isopropyl GL (glucoputranjivin, 6a), sec-butyl GL (glucocochlearin, 7a), pent-4-enyl GL (glucobrassicanapin, 2a), and 5-methylsulfanylpentyl GL (glucoberteroin, 4a) were also identified and quantified while 4-methylpentyl GL, 5-methylhexyl GL, and n-heptyl GL, were tentatively identified by GC-MS of their degradation products. Based on the major, as well as the minor GLs, this study shows differences in chemotaxonomy between F. triquetra and the related Degenia velebitica (Degen) Hayek as well as other investigated species of the genus Fibigia.

Keywords: Fibigia triquetra, Brassicaceae, glucosinolates, desulfo-glucosinolates, isothiocyanates.

Abbreviations: GL: glucosinolate; DS-GL: desulfo-glucosinolate; NT: near threatened; ITC: isothiocyanate; GC-MS: gas chromatography-mass spectrometry; HPLC-DAD: high-performance liquid chromatography - diode array detector; HPLC-ESI-MS: high-performance liquid chromatography - electrospray mass spectrometry; RPF: relative proportionality factor; GRA: glucoraphanin; GPU: glucoputranjivin; GNA: gluconapin; GCC: glucocochlearin; GBN: glucobrassicanapin; GER: glucoerucin; GBE: glucoberteroin; GAL: glucoalyssin; Met: methionine; Leu: leucine; Tyr: tyrosine; Val: valine; DNA: deoxyribonucleic acid; ITS: internal transcribed spacer; a.s.I.: above sea level.

\section{INTRODUCTION}

C ROATIA is hosting significant populations of many plant species that are threatened at the European level. One of the reasons for the large number of endemics in Croatia, and specially tertiary relics, is the fact that this area was not greatly affected by glaciation. Among the 13 known species in the genus Fibigia (Brassicaceae), ${ }^{[1]}$ two wild-growing are known in the Flora of Croatia, namely Fibigia clypeata (L.) Medik. and Fibigia triquetra (DC.) Boiss. ex Prantl. The latter species is a rare Croatian paleostenoendemic plant species included in the Croatia Red Book in the category of near threatened (NT) plants. ${ }^{[2,3]}$ F. triquetra is a perennial plant, characterized by sub-shrubby growth (up to $5-20 \mathrm{~cm}$ in height), large yellow flowers, and compact rosettes of hairy, and grey leaves. The fruit forms an elliptical or elongated ellipsoidal silique. The natural area of distribution is restricted to the rocky grounds of Dalmatia ${ }^{[4,5]}$ on altitudes ranging from 10 to $1000 \mathrm{~m}$ above sea level (a.s.l.). There is a striking similarity in morphology, anatomy, and taxonomy between $F$. triquetra and Degenia velebitica (Degen) Hayek, which was reported as a Croatian stenoendemic chasmophytic herbaceous plant. ${ }^{[6-9]}$ According to a phylogenetic relationship study, F. triquetra seems to be closer to $D$. velebitica than any other Fibigia species. ${ }^{[10]}$ The restriction fragment length PCR amplified ribosomal DNA (ITS regions), 


\section{EXPERIMENTAL}

as well as the size of the genome types of $F$. triquetra and $D$. velebitica were determined and compared. These analyses indicated that $F$. triquetra varied from $D$. velebitica.

Studies based on non-morphological characters, such as chemical features together with other biological or genetic informations can help in discriminating species and understanding real relationships among the taxa. The plants of the Brassicaceae family are strikingly chemocharacterized by the presence of thiosaccharidic secondary metabolites called glucosinolates (GLs). GLs are genetically variable within plant species. They share a common structure consisting of a $\beta$-D-glucopyrano unit bearing a NOsulfated anomeric thiohydroximate function connected to a variable aglycon side chain derived from an alpha-amino acid. The chemistry of $F$. triquetra has never been investigated, and thus its GL composition is not established. As a matter of fact, information on GLs present in other plants of the genus Fibigia are very scarce and only include early approaches regarding the characterization of the GLS present, i.e. comparison with the authentic sample on TLC, paper chromatography, and GC-MS analysis of their degradation products - which are mostly isothiocyanates (ITCS). F. eriocarpa (DC.) Boiss. seeds were reported to contain 3-methylsulfinyl propyl GL (glucoiberin, GIB), $p$-hydroxybenzyl GL (sinalbin, SNB), and benzyl GL (glucotropaeolin, GTL). ${ }^{[1]}$ Pent-4-enyl GL (glucobrassicanapin, GBN, 2a) (Figure 1) and 2-hydroxy-3-butenyl GL (progoitrin, PRO or epiprogoitrin, EPRO) were reported in the seeds of $F$. clypeata (L.) Medik. ${ }^{[12]}$ and F. macrocarpa (Boiss.) Boiss. ${ }^{[12,13]}$ Next to those GLs, F. macrocarpa was reported also to contain but-3-enyl GL (gluconapin, GNA, 1a) 4-methylsulfanylbutyl GL (glucoerucin, GER, 3a) and 4-methylsulfinylbutyl GL (glucoraphanin, GRA, 5a).[12] Bennett et al. ${ }^{[14]}$ used ion-pairing LC-MS methodology for the identification of the GLs in $F$. clypeata seeds, which confirmed the previous report of GLs, i.e. EPRO (100-125 $\mu \mathrm{mol} \mathrm{g}^{-1}$ of dry weight) and PRO (0.1-10 $\mu \mathrm{mol} \mathrm{g}^{-1}$ of dry weight). Conversely to GC-MS and other techniques previously mentioned, this latter method ensured accurate measurement of all classes of GLs. ${ }^{[14]}$

All previous reports dealt with GLs in Fibigia seeds. However, the nature of GLs and their relative amounts can vary greatly with plant species and variety, tissue type (seed, root, stem, leaf, flower) and developmental stage of the tissue. $[8,15,16]$

Thus, the aim of the present study was to investigate the qualitative and quantitative $\mathrm{GL}$ profile in the various aerial parts (flower, leaf, stem, seed) of $F$. triquetra. The identification and quantification were performed by HPLCDAD of the desulfo-glucosinolates (DS-GLs) and comparison with standards. The analyses were confirmed by direct HPLC-ESI-MS analysis of intact GLs and/or indirectly by GCMS of their breakdown products.

\section{General}

DS-GLs were analyzed on HPLC Agilent model 1100 (New Castle, Delaware, USA) equipped with a diode array detector (DAD) and an Inertsil ODS-3 column $(250 \times 3 \mathrm{~mm}$, particle size $5 \mu \mathrm{m}$,) thermostated at $30^{\circ} \mathrm{C}$. Intact GLs were analyzed on a HPLC Agilent model 1100 equipped with a quaternary pump, automatic injector, diode-array detector (wavelength range 190-600 $\mathrm{nm}$ ) degasser, and a Hypersil ODS column $(200 \times 4.6 \mathrm{~mm}$, particle size $5 \mu \mathrm{m})$. The HPLC was interfaced to an Agilent model 6120 mass spectrometer (Toronto, ON) with a Chemstation data system LC-MSD B.03.01. GC analyses were performed with a Varian model 3900 system (Varian Inc., Lake Forest, CA, USA) equipped with a Varian mass spectrometer model 2100T, non-polar capillary column VF-5MS $(30 \mathrm{~m} \times 0.25 \mathrm{~mm}$ i.d., coating thickness $0.25 \mu \mathrm{m}$; Varian Inc.). Homogenization was effected by U-Turrax (IKA T25) homogenizer.

All the solvents employed were purchased from Fluka Chemie, Buchs, Switzerland. Anhydrous sodium sulfate was obtained from Kemika, HR-Zagreb, DEAESephadex A-25 anion-exchange resin from GE Healthcare). Enzymes thioglucosidase (myrosinase EC 3.2.1.147; $361 \mathrm{U} / \mathrm{g}$ ) from Sinapis alba seeds and sulfatase Type $\mathrm{H}-1$ from Helix pomatia were purchased from Sigma-Aldrich Chemie $\mathrm{GmbH}, \mathrm{D}$-Steinheim. Glucoraphanin and gluconapin were purchased from Chromadex, USA, glucoerucin from CFM Oskar Tropitzsch, Germany, while other GLs and DS-GLs were available as pure standards isolated in the laboratory. ${ }^{[17,18]}$

\section{Plant Material}

The aerial parts (leaf-flower, stem, and seed) of Fibigia triquetra (DC.) Boiss. ex Prantl were collected on the island of Brač (Mt. Vidova Gora, 770 meters a.s.l.; Gauss-Kruger coordinates $X=5631845 ; Y=4794051)$ - near Split, during flowering in March (flower, leaf, stem) and June (seed) in 2011 from wild-growing populations. The botanical identity of the plant material was confirmed by the local botanist Dr. Mirko Ruščć, and voucher specimens (no. DBFT001) have been deposited at the Department of Biology, Faculty of Sciences, Split, Croatia.

\section{HPLC of DS-GLs and GLs}

\section{EXTRACTION OF GLS AND DESULFATION}

GLs were extracted from the different plant parts of $F$. triquetra (leaf-flower, stem, and seed) according to the EU standard procedure, ${ }^{[19]}$ albeit with some modifications. ${ }^{[15]}$ Plant samples were reduced to a fine powder. Samples of ca $500 \mathrm{mg}$ were extracted for $5 \mathrm{~min}$ at $80{ }^{\circ} \mathrm{C}$ in $2 \times 5 \mathrm{~mL}$ $\mathrm{EtOH}-\mathrm{H}_{2} \mathrm{O}(70: 30 \mathrm{v} / \mathrm{v})$, homogenized and then centrifuged. 
Supernatants were combined, and the final volume was measured. Each extract $(1 \mathrm{~mL})$ was loaded onto a minicolumn filled with $0.6 \mathrm{~mL}$ of DEAE-Sephadex A-25 anionexchange resin conditioned with $25 \mathrm{mM}$ acetate buffer (pH 5.6). After washing with $3 \mathrm{~mL}$ buffer, $200 \mu \mathrm{L}(0.35 \mathrm{U}$ $\mathrm{mL}^{-1}$ ) of purified sulfatase ${ }^{[20]}$ was loaded onto the minicolumn which was left on the bench overnight. The DSGLs were then eluted with $3 \mathrm{~mL}$ of ultra pure $\mathrm{H}_{2} \mathrm{O}$ and were analyzed by HPLC-DAD.

In addition, seeds (540 mg) were frozen in liquid $\mathrm{N}_{2}$ and ground with a mortar and pestle. The powder was extracted for $5 \mathrm{~min}$ at $80^{\circ} \mathrm{C}$ in $2 \times 5 \mathrm{~mL} \mathrm{EtOH}-\mathrm{H}_{2} \mathrm{O}(70: 30 \mathrm{v} / \mathrm{v})$. The solutions were combined and evaporated under reduced pressure and intact GLs were analyzed by HPLC-ESI-MS.

\section{HPLC-DAD ANALYSIS}

The chromatography of DS-GLs ( $20 \mu \mathrm{L}$ injected solution) was performed with an Inertsil ODS-3 column at a flow rate of $1 \mathrm{~mL} \mathrm{~min}{ }^{-1}$ eluting with a gradient of $\mathrm{H}_{2} \mathrm{O}(\mathrm{A})$ and acetonitrile (B) following the program: 1 min $1 \% \mathrm{~B} ; 22$ min linear gradient up to $22 \%$ B; 3 min linear gradient down to $1 \%$ B. DS-GLs were detected monitoring the absorbance at $229 \mathrm{~nm} \cdot{ }^{[15]}$

\section{HPLC-ESI-MS ANALYSIS}

The extract ( $121.3 \mathrm{mg}$ ) was dissolved in $4 \mathrm{~mL}$ EtOH$-\mathrm{H}_{2} \mathrm{O}$ (70:30 v/v)and filtered through a plug of cotton prior to HPLC analysis, which was performed by injecting a $5 \mu \mathrm{L}$ aliquot of the solution of crude extract into HPLC-ESI-MS. The two mobile phase solvents, $\mathrm{MeOH}$ and $\mathrm{H}_{2} \mathrm{O}$, were prepared with $0.15 \% \mathrm{Et}_{3} \mathrm{~N}$ and $0.18 \% \mathrm{HCO}_{2} \mathrm{H}$, added as ion-pairing reagents. Both solutions were filtered using $0.45 \mu \mathrm{m}$ nylon membranes. The initial mobile phase was $100 \% \mathrm{HPLC}$-grade $\mathrm{H}_{2} \mathrm{O}$. At $10 \mathrm{~min}$, the mobile phase was switched to a linear gradient of $100 \% \mathrm{H}_{2} \mathrm{O}$ to $100 \% \mathrm{MeOH}$ over $60 \mathrm{~min}$. After each run, the initial mobile phase conditions were set and the system was allowed to equilibrate. The flow rate was kept constant at $1 \mathrm{~mL} \mathrm{~min}{ }^{-1}$. The column was maintained at room temperature.

The electrospray interface was a standard ES source operating with a capillary voltage of $4 \mathrm{kV}$ and temperature of $350{ }^{\circ} \mathrm{C}$. The system was operated in the negative and positive ion electrospray modes. Nitrogen was used as nebulizing and drying gas at a flow rate of $10 \mathrm{~L} \mathrm{~min}^{-1}$ (35 psig). The mass spectrometer was programmed to perform full scans between $\mathrm{m} / \mathrm{z} 100$ and 1,000.[21]

\section{GC-MS Analysis of GL Breakdown Products}

\section{ENZYMATIC HYDROLYSIS OF GLS AND EXTRACTION}

Crushed and dried flower with leaf (10 g), stem (10 g), and seed (1 g), were homogenized separately with deionised $\mathrm{H}_{2} \mathrm{O}(100 \mathrm{~mL}, \mathrm{pH} \sim 6)$ and myrosinase
(1-2 units, Sigma), then allowed to hydrolyze during $17 \mathrm{~h}$ at room temperature (ca $30{ }^{\circ} \mathrm{C}$ ). Sufficient redistilled $\mathrm{CH}_{2} \mathrm{Cl}_{2}(3 \times 20 \mathrm{~mL})$ was then added, the mixtures were shaken for $30 \mathrm{~min}$ and separated by centrifugation for $5 \mathrm{~min}$ at $4,000 \mathrm{rpm}$. The separated organic layer was dried over anhydrous sodium sulfate and concentrated to $100 \mu \mathrm{L}$. All the obtained hydrolyzates were kept (in a tightly closed vial) in a freezer at $-20^{\circ} \mathrm{C}$ until GC-MS analysis. [22]

\section{GC-MS ANALYSIS}

Chromatographic conditions were as follows: helium was the carrier gas at $1 \mathrm{~mL} \mathrm{~min}{ }^{-1}$, injector temperature was $250^{\circ} \mathrm{C}$. VF-5MS column temperature was programmed at $60{ }^{\circ} \mathrm{C}$ isothermal for $3 \mathrm{~min}$, and then increased to $246^{\circ} \mathrm{C}$ at a rate of $3{ }^{\circ} \mathrm{C} \mathrm{min}-1$ and held isothermal for $25 \mathrm{~min}$. The injected volume was $1 \mu \mathrm{L}$ and the split ratio was $1: 20$. MS conditions were: ionization voltage $70 \mathrm{eV}$; ion source temperature $200{ }^{\circ} \mathrm{C}$; mass scan range: $40-350$ mass units. The analyses were carried out in duplicate. ${ }^{[23]}$

\section{Identification and Quantification}

The identification of DS-GLs was performed on the basis of the retention time and UV spectra of each DS-GL compared with pure standards. ${ }^{[20]}$ The GL amount was quantified by using a calibration curve of pure DS-sinigrin solution (range from 0.14 to $1.4 \mathrm{mM}, y=36.3+5854.3 \cdot x$, $R^{2}=0.9998$, LOD (limit of detection) $0.013 \mathrm{mM}$, LOQ (limit of quantitation) $0.041 \mathrm{mM}$. LOD and LOQ were both determined based on the DS-sinigrin calibration curve according to the European Medicines Agency (EMEA) guidelines relating to the validation of analytical methods ${ }^{[24]}$ ) and RPFs for each individual DS-GL. The published RPFs for DS-GLs ${ }^{[18,25]}$ were used, with the exception of $\mathbf{5 b}$, for which an arbitrary RPF value equal to 1 was set.

Peaks of the intact GLs, $\mathbf{1} \mathbf{a}, \mathbf{3} \mathbf{a}$, and $\mathbf{5 a}$, were identified by comparison of UV spectra, retention times and mass spectra of commercial standards in the LC-MS library. Glucoberteroin (5-methylsulfanylpentylGL, GBE, 4a) was identified by comparison of the UV spectrum, retention time and mass spectrum with those of a previously isolated GBE stored in the LC-MS library. ${ }^{[17]}$

Individual peaks of volatiles were identified by comparing their retention indices and mass spectra to those of authentic samples, as well as by computer matching against the Wiley 275-library spectra database and comparison of the mass spectra with literature data. ${ }^{[26]}$ The percentages in Table 2 and 3 were calculated as the mean value of component percentages on column VF-5MS column for analyses run in duplicate. 


\section{RESULTS}

The aerial parts of Fibigia triquetra leaf - flower, stem and seed were analysed for GL identification and quantification. The extractions were made according to the EU official method. Each extraction was performed in duplicate. The structures of the major GLs and their DS-counterparts are given in Figure 1. The obtained HPLC chromatograms are given in Figure 2 and the GL contents are summarised in Table 1 . The identity of each DS-GL was determined by the comparison of the $t_{\mathrm{R}}$ and UV spectra of each product with those of DS-GL standards.

The leaf - flower extract and the stem extract of $F$. triquetra showed almost the same DS-GL chromatographic qualitative profile. DS-GNA (1b) - the major DS-GL in both samples - DS-GER (3b) and DS-GRA (5b) were identified at $t_{R} 9.4,5.2$, and $14.3 \mathrm{~min}$, respectively. In contrast to other plant parts analysed, the major DS-GL identified in seed extracts was $\mathbf{3 b}$, followed by $\mathbf{1} \mathbf{b}$ and $\mathbf{5 b}$.

The other minor DS-GLs present in all the samples were DS-GPU (desulfo isopropyl GL, 6b) and DS-GCC (desulfo sec-butyl GL, 7b). In addition, DS-GBN (desulfo pent-4-enyl GL, 2b) was detected in the stem, and DS-GBE (desulfo 5-methylsulfanylpentyl GL, $\mathbf{4 b}$ ) in the seed only. The structures of those minor GLs and their DScounterparts are also given in Figure 1. The HPLC chromatograms showed also unidentified peaks at 20.1 and $20.9 \mathrm{~min}$ (seed extract) as well as at $21.6 \mathrm{~min}$ (flower - leaf extract) which did not match with any of our available standards.

For GL quantification, we used the relative proportionality factors (RPFs) reported in the literature. ${ }^{[18,24]}$ Since the RPFs for DS-GCC and DS-GBE are not reported, we used an arbitrary RPF value of 1 for DSGCC, whereas for DS-GBE the RPF of DS-GER was used. The results for quantification are given in Table 1 . In comparison to the stem extract, the leaf - flower extract showed a similar content of the major GLs, i.e. 77.9 and $68.2 \%$ of $1 \mathrm{a}$, 12.8 and $15.4 \%$ of $5 a$, and 5.6 and $8.7 \%$ of $3 a$, respectively. The seed contained $56.6 \%$ of $3 a, 24.1 \%$ of $1 a$, and $17.3 \%$ of $\mathbf{5 a}$. The total GL content is strikingly high in all aerial parts, with the highest content in the seed. It is worth mentioning that the upper plant parts (leaf - flower and stem) have a $2-3$ fold higher content of $5 a$ than $\mathbf{3 a}$, while this content in the seed is vice versa. This phenomenon was previously reported for $D$. velebitica ${ }^{[8]}$ and Raphanus sativus L. ${ }^{[27]}$ and one could speculate a biological oxidation of $3 \mathbf{a}$ to $\mathbf{5 a}$ during the sprouting of the seeds.

The identification of GLs was confirmed by the GC-MS analysis of the corresponding volatile degradation products resulting from enzymatic hydrolysis. The most common breakdown products are ITCs, which are characterised by odd mass of the molecular ion, and a

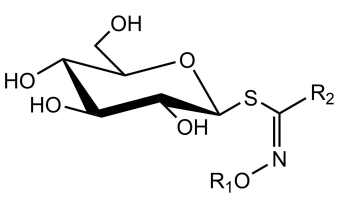

\begin{tabular}{ccc} 
& $\mathrm{R}_{\mathbf{1}}$ & $\mathrm{R}_{2}$ \\
\hline 1a & $\mathrm{SO}_{3}^{-}$ & $\mathrm{CH}_{2}=\mathrm{CH}-\left(\mathrm{CH}_{2}\right)_{2}$ \\
2a & $\mathrm{SO}_{3}{ }^{-}$ & $\mathrm{CH}_{2}=\mathrm{CH}-\left(\mathrm{CH}_{2}\right)_{3}$ \\
3a & $\mathrm{SO}_{3}^{-}$ & $\mathrm{CH}_{3}-\mathrm{S}-\left(\mathrm{CH}_{2}\right)_{4}$ \\
4a & $\mathrm{SO}_{3}^{-}$ & $\mathrm{CH}_{3}-\mathrm{S}-\left(\mathrm{CH}_{2}\right)_{5}$ \\
5a & $\mathrm{SO}_{3}^{-}$ & $\mathrm{CH}_{3}-\mathrm{SO}-\left(\mathrm{CH}_{2}\right)_{4}$ \\
6a & $\mathrm{SO}_{3}^{-}$ & $\mathrm{CH}_{3}-\mathrm{CH}\left(\mathrm{CH}_{3}\right)$ \\
7a & $\mathrm{SO}_{3}^{-}$ & $\mathrm{CH}_{3}-\mathrm{CH}_{2}-\mathrm{CH}\left(\mathrm{CH}_{3}\right)$
\end{tabular}

\begin{tabular}{ccc} 
& $\mathrm{R}_{1}$ & $\mathrm{R}_{2}$ \\
\hline $1 \mathrm{~b}$ & $\mathrm{H}$ & $\mathrm{CH}_{2}=\mathrm{CH}-\left(\mathrm{CH}_{2}\right)_{2}$ \\
$2 \mathrm{~b}$ & $\mathrm{H}$ & $\mathrm{CH}_{2}=\mathrm{CH}-\left(\mathrm{CH}_{2}\right)_{3}$ \\
$3 \mathrm{~b}$ & $\mathrm{H}$ & $\mathrm{CH}_{3}-\mathrm{S}-\left(\mathrm{CH}_{2}\right)_{4}$ \\
$4 \mathrm{~b}$ & $\mathrm{H}$ & $\mathrm{CH}_{3}-\mathrm{S}-\left(\mathrm{CH}_{2}\right)_{5}$ \\
$5 \mathrm{~b}$ & $\mathrm{H}$ & $\mathrm{CH}_{3}-\mathrm{SO}-\left(\mathrm{CH}_{2}\right)_{4}$ \\
$6 \mathrm{~b}$ & $\mathrm{H}$ & $\mathrm{CH}_{3}-\mathrm{CH}\left(\mathrm{CH}_{3}\right)$ \\
$7 \mathrm{~b}$ & $\mathrm{H}$ & $\mathrm{CH}_{3}-\mathrm{CH}_{2}-\mathrm{CH}\left(\mathrm{CH}_{3}\right)$
\end{tabular}

Figure 1. Chemical structures of GLs in F. triquetra: gluconapin (1a), glucobrassicanapin (2a), glucoerucin (3a), glucoberteroin (4a), glucoraphanin (5a), glucoputranjivin (6a), glucocochlearin (7a), and their desulfo-counterparts $(1 b-7 b)$.
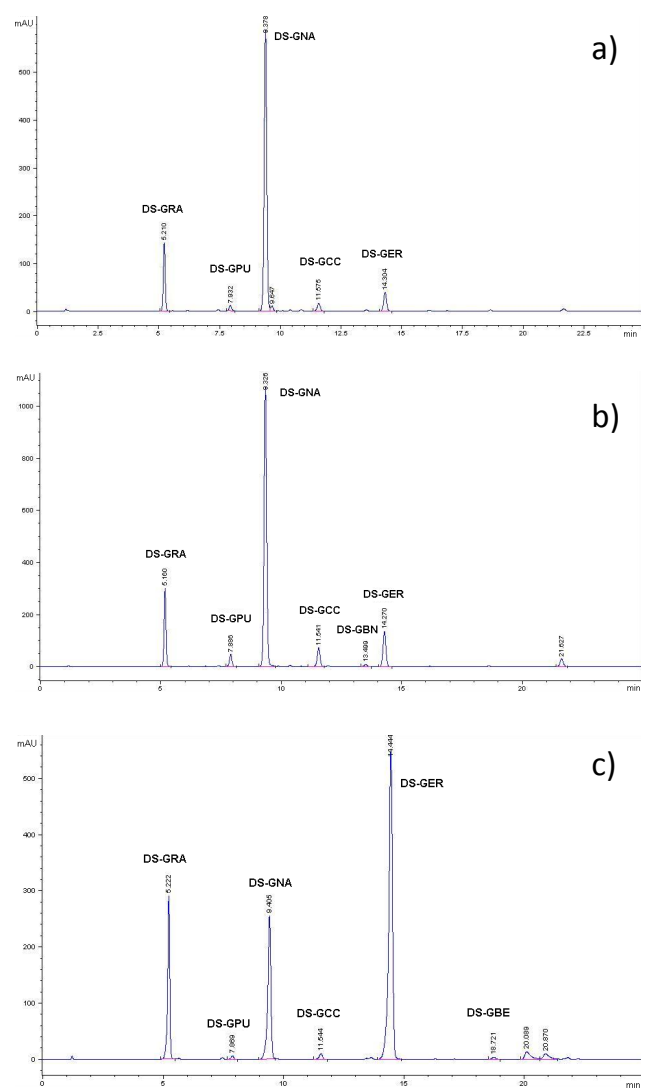

Figure 2. HPLC-DAD chromatograms of DS-GLs isolated from a) leaf and flower; b) stem; c) seed of F. triquetra. Peaks correspond to GLs, as follows: DS-GRA, desulfo-glucoraphanin; DS-GPU, desulfo-glucoputranjivin; DS-GNA, desulfo-gluconapin; DS-GCC, desulfo-glucocochlearin; DSGBN, desulfo-glucobrassicanapin; DS-GER, desulfo-glucoerucin; DS-GBE, desulfo-glucoberteroin. 
Table 1. GL content of leaf-flower, stem, and seed in F. triquetra.

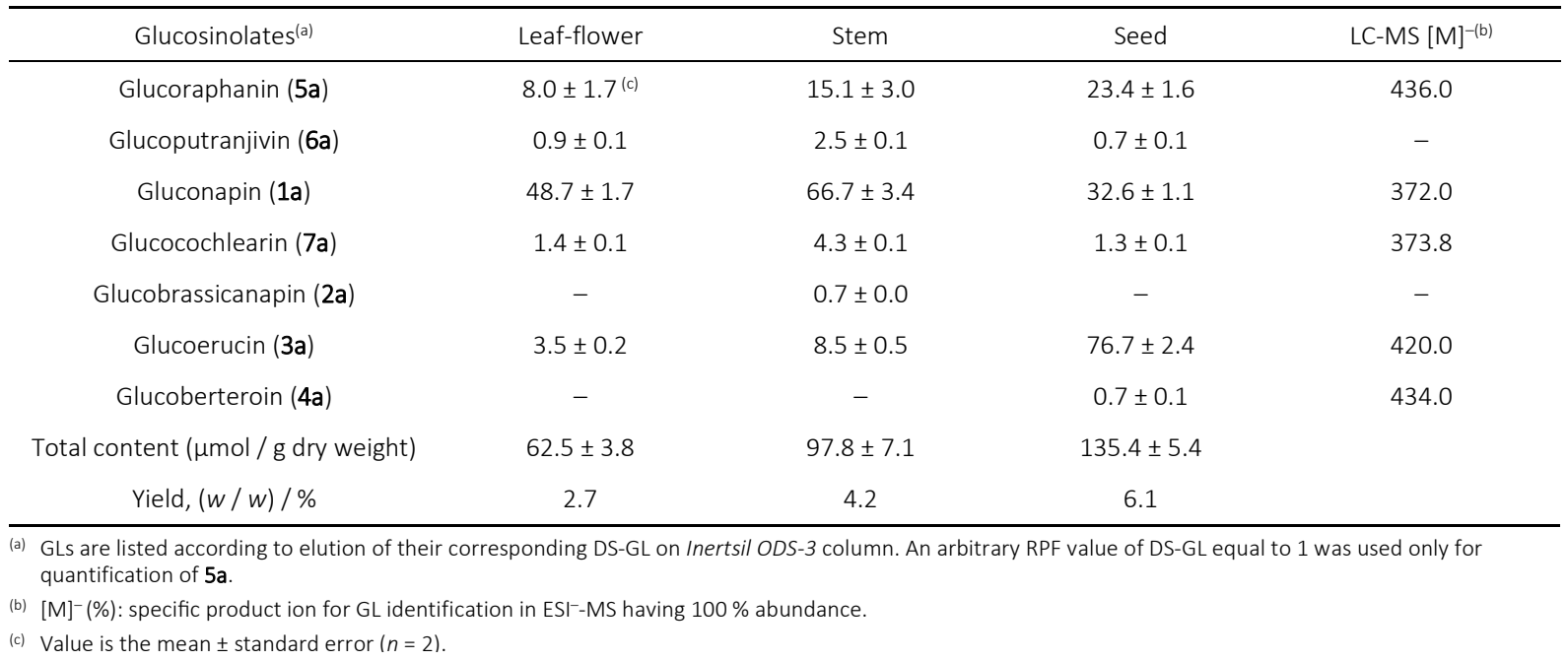

fragment ion of $m / z=72$. Some GLs form unstable ITCs, such as 2-hydroxyalkenyl ITCs which cyclize to oxazolidine2-thiones, while 4-hydroxybenzyl ITC and the very reactive indole ITCs are degraded into their corresponding alcohols, releasing the thiocyanate ion. ${ }^{[28]}$ Beside identified ITCS, other breakdown products, mostly nitriles, can be helpful in confirming the parent GL identification. Individual GLS identified by GC-MS analysis of their hydrolysis products in different $F$. triquetra plant parts are shown in Table 2.

GC-MS analysis confirmed the presence of the GLS identified by HPLC analysis of the corresponding DS-GLs, through detection of the following ITCs: i) isopropyl- and sec-butyl ITCs, originating from the branched GLs, 6a, and $7 a$, respectively; ii) but-3-enyl- and pent-4-enyl ITCs, from olefinic GLs 1a and 2a; and iii) 4-methylsulfanylbutyl(erucin), 5-methylsulfanylpentyl- (berteroin) and 4-methylsulfinylbutyl (sulforaphane) ITCs confirming $\mathbf{3 a} \mathbf{3} \mathbf{4 a}$, and $\mathbf{5 a}$, respectively. In addition to the present ITCs, 5-(methyIsulfanyl)pentanenitrile confirmed the presence of 3a. GCMS analysis was particularly useful for the correct identification of two minor peaks, namely $6 \mathbf{a}$ and $7 \mathbf{a}$. Three additional minor ITCs, 4-methylpentyl-, 5-methylhexyl-, and $n$-heptyl ITCs were detected via GC-MS analysis. Those GL breakdown products belonging to the saturated C- 6 and C-7 aliphatic group were tentatively identified by their $t_{R}$ and MS spectra.

DS-GLs often bring difficulties in interpreting results of the individual GLs, due to concerns over the impact of $\mathrm{pH}$ value, time, and enzyme sulfatase (EC 3.1.6.1) concentration on desulfation products. ${ }^{[18,29]}$ In addition, some GL breakdown products lack volatility or prove unstable in the conditions used during the analysis, and this represents a major drawback of this indirect method. ${ }^{[30]}$ Therefore, a direct analysis of intact GLs present in the seed was performed by LC-MS for more specific and accurate qualitative determination and for better interpretation of analytical results. Specific product ion for GL identification

Table 2. Individual GLs identified by GC-MS analysis of their hydrolysis products in different $F$. triquetra plant parts.

\begin{tabular}{|c|c|c|c|c|}
\hline $\begin{array}{c}\text { Parent GL } \\
\text { Identified compound }\end{array}$ & $\mathrm{RI}^{(\mathrm{a})}$ & $\begin{array}{l}\text { Leaf- } \\
\text { flower }\end{array}$ & Stem & Seed \\
\hline Glucoputranjivin (6a) & & & & \\
\hline $\begin{array}{l}\text { Isopropyl isothiocyanate } \\
\text { Glucocochlearin (7a) }\end{array}$ & 836 & 0.4 & 1.6 & 0.9 \\
\hline $\begin{array}{l}\text { sec-Butyl isothiocyanate } \\
\text { Gluconapin (1a) }\end{array}$ & 939 & $-(\mathrm{b})$ & - & 0.7 \\
\hline $\begin{array}{l}\text { But-3-enyl isothiocyanate } \\
\text { Glucobrassicanapin (2a) }\end{array}$ & 998 & 22.9 & 48.7 & 32.0 \\
\hline $\begin{array}{c}\text { Pent-4-enyl isothiocyanate } \\
\text { 4-Methylpentyl GL }\end{array}$ & 1090 & 0.2 & 0.2 & 0.2 \\
\hline $\begin{array}{l}\text { 4-Methylpentyl isothiocyanate } \\
n \text {-Heptyl GL }\end{array}$ & 1169 & 0.2 & 0.1 & 0.1 \\
\hline $\begin{array}{l}\text { n-Heptyl isothiocyanate } \\
\text { 5-Methylhexyl GL }\end{array}$ & 1269 & $\operatorname{tr}$ & 0.4 & 0.3 \\
\hline $\begin{array}{l}\text { 5-Methylhexyl isothiocyanate } \\
\text { Glucoerucin (3a) }\end{array}$ & 1276 & - & 0.2 & 0.1 \\
\hline 5-Methylsulfanylpentanenitrile & 1213 & - & $\operatorname{tr}^{(c)}$ & $\operatorname{tr}$ \\
\hline $\begin{array}{c}\text { 4-Methylsulfanylbutyl } \\
\text { isothiocyanate (erucin) } \\
\text { Glucoberteroin (4a) }\end{array}$ & 1457 & 0.3 & 4.7 & 6.0 \\
\hline $\begin{array}{l}\text { 5-Methylsulfanylpentyl } \\
\text { isothiocyanate (berteroin) }\end{array}$ & 1542 & - & - & 0.3 \\
\hline $\begin{array}{c}\text { Glucoraphanin (5a) } \\
\text { 4-Methylsulfinylbutyl } \\
\text { isothiocyanate (sulforaphane) }\end{array}$ & 1791 & 4.3 & 5.5 & 3.3 \\
\hline Group sum / \% & & 28.3 & 61.4 & 43.9 \\
\hline
\end{tabular}


in $\mathrm{ESI}^{-}-\mathrm{MS}$, having abundance $100 \%$, is given in Table 1. The major intact GLs, $\mathbf{1 a}, \mathbf{3 a}$, and $\mathbf{5 a}$, as well as $\mathbf{4 a}$ were clearly identified in chromatograms of crude seed extracts. GCC (7a) peak, notwithstanding the low amount (1.0\%), was also observed with specific product ion 373.8 (100\%). On the contrary, LC-MS analysis of intact GLs in the seed did not allow to confirm the presence of either $2 a$ or $6 a$, previously identified by their corresponding DS-GLs and ITCs (Tables 1 and 2). Moreover, it was not possible to confirm the tentatively identified 4-methylpentyl-, 5-methylhexyl- and $n$-heptyl GLs hypothesized by GC-MS

Table 3. GC-MS analysis of miscellaneous volatile compounds from different $F$. triquetra plant parts.

\begin{tabular}{cccccc}
\hline Identified compound & $\mathrm{RI}^{(\mathrm{a})}$ & $\begin{array}{c}\text { Leaf- } \\
\text { flower }\end{array}$ & Stem & Seed \\
\hline Alkanes & & & & \\
1-Phenyl-1-propanone & 1178 & $\operatorname{tr}^{(\mathrm{b})}$ & $\mathrm{tr}$ & - (c) \\
Tricosane & 2300 & 0.9 & - & 0.5 \\
Pentacosane & 2500 & 1.9 & - & - \\
Heptacosane & 2700 & 12.9 & 2.6 & 2.6 \\
Octacosane & 2800 & 3.4 & 0.7 & 0.5
\end{tabular}

Phenols, phenylpropane derivatives and related compounds

\begin{tabular}{|c|c|c|c|c|}
\hline 2-Phenylethyl alcohol & 1133 & $\operatorname{tr}$ & 0.7 & - \\
\hline Eugenol & 1366 & 0.3 & 0.3 & - \\
\hline $\begin{array}{l}\text { 4-Hydroxy-3-methoxy } \\
\text { benzaldehyde }\end{array}$ & 1422 & $\operatorname{tr}$ & - & - \\
\hline Dihydroactinidiolide & 1547 & - & 0.1 & 0.1 \\
\hline $\begin{array}{l}\text { 6,10,14-Trimethyl-2- } \\
\text { pentadecanone }\end{array}$ & 1838 & 0.3 & - & 0.5 \\
\hline
\end{tabular}

Fatty acids and esters

$\begin{array}{ccccc}\text { Octanoic acid } & 1216 & \text { tr } & - & - \\ \text { Nonanoic acid } & 1310 & \operatorname{tr} & - & \operatorname{tr} \\ \text { Decanoic acid } & 1405 & \operatorname{tr} & \operatorname{tr} & \text { tr } \\ \text { Dibutyl phtalate } & 1861 & 0.3 & 0.4 & \operatorname{tr} \\ \text { Pentadecanoic acid } & 1890 & \operatorname{tr} & \operatorname{tr} & 0.2 \\ \text { Hexadecanoic acid } & 2017 & 19.9 & 12.6 & 19.0 \\ \text { Ethyl linoleate } & 2195 & 25.7 & 15.0 & 23.7\end{array}$

Other compounds

$\begin{array}{ccccc}\text { Dimethyl trisulfide } & 981 & \operatorname{tr} & 0.1 & 0.1 \\ \text { Dimethyl tetrasulfide } & 1228 & \operatorname{tr} & 0.9 & 1.0 \\ \text { Phytol } & 2110 & 0.2 & 1.9 & -\end{array}$

\begin{tabular}{cccc} 
Group sum / \% & 65.8 & 35.3 & 48.2 \\
Total sum / \% & 94.2 & 96.9 & 92.3 \\
\hline
\end{tabular}

\footnotetext{
(a) Same as in Table 2.

(b) tr: traces.

(c) -: not detected.
}

analysis of ITCs (Table 2). Hence, the three HPLC peaks of DS-GLs at 20.1, 20.9 and 21.6 min could not be assigned (Figure 1).

With the exception of the above-mentioned molecules, all volatile fractions from the investigated species contained compounds devoid of nitrogen or sulfur (Table 3) - mostly fatty acids, esters, alkanes, phenols, phenylpropanoids and related derivatives. The major products belonging to this class were hexadecanoic acid (12.6-19.9\%) and ethyl linoleate (15.0-25.7\%).

\section{DISCUSSION}

Glucosinolate profile analyses in the diverse plant tissues of Fibigia triquetra revealed aliphatic GLs to be the major ones. The C-4 and C-5 GLs 1a-5a originate from L-methionine (Met) via chain elongation by one carbon atom at a time, while C-3 and C-4 GLs $6 \mathbf{a}$ and $7 a$ are derived from L-valine (Val) and L-leucine (Leu), respectively. The suggested natural occurrence of C-6 and C-7 GLs, 4-methylpentyl-, 5-methylhexyl-, and $n$-heptyl GLs in a plant also accumulating similar Met-, Val-, and Leu-derived GLs seems likely. Reports of alkyl GLs bearing C- 6 and longer chains are scarce and analyses revealing their occurrence are mostly based on GC-MS of the derived ITCs. ${ }^{[31]}$ The presence of Leu-derived 4-methylpentyl $\mathrm{GL}^{[32]}$ was previously reported in Alyssoides utriculata (L.) Medik., Raphanus sativus L., Eruca sativa Mill by using GC-MS analysis of the ITC [33-36] and LC-MS analysis of intact GLs. ${ }^{[37,38]}$ Natural occurrence of both 5-methylhexyland $n$-heptyl GLs was also inferred from GC-MS analysis of their breakdown products. Val-derived 5-methylhexyl G[${ }^{[32]}$ was previously inferred from 5-methylhexyl ITC analysis, while identification of $n$-heptyl GL was based on degradation to octanenitrile and $n$-heptyl ITC. ${ }^{[16,33,34]}$ It is worth mentioning that until recent years, $n$-heptyl GL has been considered "unnatural" as claimed for example by Botting et al. [39]

The present study has shown that C-4 GLs i.e. 1a, 3a, $5 \mathbf{a}$ are the major ones in F. triquetra whereas a C-5 GL, 4a, is dominant in $D$. velebitica. In addition, minor GLs can be suggested to be important tags which differentiate F. triquetra from $D$. velebitica. Our previous investigation of $D$. velebitica has shown the presence of glucoaubrietin (4-methoxybenzyl GL), as one minor GL present in the seed. Thus it seems that, next to the major Met-derived GLs, F. triquetra accumulates also Val- and Leu-derived GLs, whereas $D$. velebitica accumulates Tyr-derived GLs, next to the major Met-derived GLs. Earlier reports on other Fibigia species showed prevalence of C-4 GLS such as $\mathbf{1 a}$ and $\mathbf{5 a}$, but also of $(R)$ - and (S)-2-hydroxy-3-butenyl GLs (PRO and EPRO), which were not identified in F. triquetra. ${ }^{[11-14]}$

Our group has previously focused on the GL profile of endemic plants of the tribe Alysseae, which comprises seven genera: Alyssoides, Alyssum, Aurinia, Berteroa, Clypeola, 
Degenia and Fibigia. Those investigations ${ }^{[8,15,16,31,33]}$ of, namely, D. velebitica, Aurinia sinuata (L.) Griseb. and $A$. leucadea (Guss.) C. Koch., suggest that species in this tribe represent appropriate sources for Met-derived GLs bearing a C-4 and/or C-5 olefinic aglycon chain (1a, 2a) and/or a thiofunctionalized chain (3a-5a, GAL). With high GLcontents ranging from 9.9 to $135.4 \mu \mathrm{mol} \mathrm{g} \mathrm{g}^{-1}$ of dried material in different plant parts - especially in the seed (over $4.0 \% \mathrm{w} / \mathrm{w}$ with the highest, $6.1 \% \mathrm{w} / \mathrm{w}$ in F. triquetra) - those Alysseae are found to represent a good GL source.

\section{CONCLUSIONS}

The GLs of an ice-age survived plant $F$. triquetra were analyzed by using a multiple method approach, involving HPLCDAD analysis of DS-GLs and their comparison to standards, HPLC-ESI-MS analysis of intact GLs and GC-MS of the breakdown products obtained by enzymatic degradation of GLs. This approach established the qualitative and quantitative $\mathrm{GL}$ profile of $F$. triquetra and the present study revealed differences in the GL chemistry with the most similar paleostenoendemic plant Degenia velebitica, the only species in this genus.

Acknowledgment. This work was performed in the frame of the COGITO project "Glucosinolates - Novel Sources and Biological Potential" which was jointly supported by the Croatian Ministry of Science, Education and Sports and the French Ministry of Foreign Affairs. Financial support from the Natural Sciences and Engineering Research Council of Canada, Laurentian University and Canadian Foundation for Innovation (Leaders Opportunity Fund)-Ontario Research Fund is gratefully acknowledged by S. M.

\section{REFERENCES}

[1] O. Çetin, A. Duran, E. Martin, S. Tustas, Afr. J. Biotechnol. 2012, 11, 109.

[2] P. Fukarek, E. M. Šolić, Acta Biokovica 1982, 2, 243.

[3] V. Kostović-Vranješ, B. Bohanec, B. Javornik, D. Papeš in: Variabilty of ITS region of nrDNA among stenoendemical species of Croatian Fibigia triquetra and two Fibigia species from Macedonia (Brassicaceae) (Ed. B. Vitale), Periodicum Biologorum, Hvar, Hrvatska, 1998, p. 30.

[4] V. Kostović-Vranješ, D. Vladović, D. Papeš, Period. Biol. 1994, 96, 372.

[5] B. Prevalek-Kozlina, V. Kostović-Vranješ, D. Slade, Plant Cell Tiss. Org. Cult. 1997, 51, 141.

[6] E. Mayer, Acta Biokovica 1981, 1, 283.

[7] B. Pevalek-Kozlina, M. Pavlica, M. Vujević, PhytonAnn Rei Bot A 1999, 39, 293.

[8] G. R. De Nicola, I. Blažević, S. Montaut, P. Rollin,
J. Mastelić, R. Iori, A. Tatibouët, Chem. Biodiversity 2011, 8, 2090.

[9] J. Mastelić, I. Blažević, I. Kosalec, Chem. Biodiversity 2010, 7, 2755.

[10] I. Rešetnik, Z. Satovic, G. M. Schneeweiss, Z. Liber, Mol. Phylogenet. Evol. 2013, 69, 772.

[11] H. A. Boudjikanian, M. M. Abdel Gawad, J. Raynaud, Planta Med. 1974, 26, 144.

[12] I. A. Al-Shehbaz, K. I. Al-Shammary, Biochem. Syst. Ecol. 1987, 15, 559.

[13] M. E. Daxenbichler, G. F. Spencer, D. G. Carlson, G. B. Rose, A. M. Brinker, R. G. Powell, Phytochemistry 1991, 30, 2623.

[14] R. N. Bennett, F. A. Mellon, P. A. Kroon, J. Agric. Food Chem. 2004, 52, 428.

[15] I. Blažević, A. Radonić, M. Skočibušić, G. R. De Nicola, S. Montaut, R. Iori, P. Rollin, J. Mastelić, M. Zekić, A. Maravić, Chem. Biodiversity 2011, 8, 2310.

[16] I. Blažević, G. R. De Nicola, S. Montaut, P. Rollin, Nat. Prod. Commun. 2013, 8, 1463.

[17] S. Montaut, J. Grandbois, L. Righetti, J. Barillari, R. Iori, P. Rollin, J. Nat. Prod. 2009, 72, 889.

[18] J.-P. Wathelet, R. Iori, O. Leoni, P. Rollin, A. Quinsac, S. Palmieri, Agroindustria 2004, 3, 257.

[19] E. N. European Economic Community Commission Regulation, Off. J. Eur. Comm. 1990, 27.

[20] O. Leoni, R. Iori, T. Haddoum, M. Marlier, J. P. Wathelet, P. Rollin, S. Palmieri, Ind. Crop. Prod. 1998, 7, 335.

[21] C. L. Zrybko, E. K. Fukuda, R. T. Rosen, J. Chromatogr. A 1997, 767, 43.

[22] I. Blažević, A. Radonić, J. Mastelić, M. Zekić, M. Skočibušić, A. Maravić, Food Chem. 2010, 121, 1020.

[23] N. Bezić, E. Vuko, V. Dunkić, M. Ruččić, I. Blažević, F. Burčul, Molecules 2011, 16, 8119.

[24] European Medicines Agency (EMEA), Quality guidelines: Validation of analytical procedures: Text and methodology (ICHQ2), http://www.ema.europa.eu/ docs/en_GB/document_library/Scientific_guideline/20 09/09/WC500002662.pdf. (Accessed on December the $1^{\text {st }}$ 2015).

[25] D. B. Clarke, Anal. Methods 2010, 2, 310.

[26] R. P. Adams, Identification of essential oils components by gas chromatography/quadrupole mass spectrometry, Allured Publishing Cooperation, Illinois, 2001.

[27] J. Barillari, D. Canistro, M. Paolini, F. Ferroni, G. F. Pedulli, R. Iori, L. Valgimigli, J. Agric. Food Chem. 2005, 53, 2475.

[28] F. S. Hanschen, E. Lamy, M. Schreiner, S. Rohn, Angew. Chem. Int. Ed. 2014, 53, 11430.

[29] K. Hennig, R. Verkerk, G. Bonnema and M. Dekker, Food Chem. 2012, 134, 2355. 
[30] W. C. K. Chiang, D. J. Pusateri, R. E. A. Leitz, J. Agric. Food Chem. 1998, 46, 1018.

[31] I. Blažević, S. Montaut, G. R. De Nicola, P. Rollin, Nat. Prod. Commun. 2015, 10, 1043.

[32] Y. Sawada, A. Kuwahara, M. Nagano, T. Narisawa, A. Sakata, K. Saito, M. Yokota Hirai, Plant Cell Physiol. 2009, 50, 1181.

[33] I. Blazevic, F. Burcul, M. Ruscic, J. Mastelic, Chem. Nat. Compd. 2013, 49, 374.

[34] I. Blažević, J. Mastelić, Food Chem. 2009, 113, 96.
[35] J. W. Fahey, A. T. Zalcmann, P. Talalay, Phytochemistry 2001, 56, 5.

[36] J. Mastelić, I. Jerković, I. Blažević, A. Radonić, L. Krstulović, Talanta 2008, 76, 885.

[37] F. Lelario, G. Bianco, S. A. Bufo, T. R. I. Cataldi, Phytochemistry 2012, 73, 74.

[38] T. R. I. Cataldi, A. Rubino, F. Lelario, S. A. Bufo, Rapid Commun. Mass Spectrom. 2007, 21, 2374.

[39] N. E. Davidson, T. J. Rutherford, N. P. Botting, Carbohydr. Res. 2001, 330, 295. 